\title{
Intrafollicular amyloid in primary hyperparathyroidism
}

\author{
P. W. LEEDHAM AND D. J. POLLOCK \\ From the Institute of Pathology, The London Hospital
}

SYNOPSIS The histology of the parathyroids from 88 cases of primary hyperparathyroidism has been reviewed in a search for local amyloid deposits.

Characteristic intrafollicular amyloid deposits of varying extent were found in nine cases. The case histories of these show that seven had suspected or proven pluriglandular adenomatosis but that the remainder had no such associations. The material studied shows no correlation with systemic primary or secondary amyloidosis.

The significance of these findings is discussed in relation to the pluriglandular syndrome, peptide hormones, medullary carcinoma of the thyroid, and calcitonin secretion. It is suggested that amyloid in this context may be a 'marker' for secretion of a peptide closely related to calcitonin.

Local deposition of amyloid in tumours of endocrine glands is well documented in medullary carcinoma of the thyroid and islet cell tumours of the pancreas (Porta, Yerry, and Scott, 1962; Williams, Brown, and Doniach, 1966). The finding of fairly large amounts of amyloid in a parathyroid removed for primary hyperparathyroidism and showing chief cell hyperplasia prompted a search for further cases.

\section{Methods}

Material from 88 patients was examined; 66 were from the London Hospital of whom 64 were cases of surgically treated primary hyperparathyroidism and two were necropsies to which our attention was drawn during the survey. The remaining 22 patients had parathyroids removed for primary hyperparathyroidism at King's College Hospital. Forty cases showed chief cell adenomas and 48 primary hyperplasia (Table I).

Haematoxylin-and-eosin-stained sections were screened for deposits of amorphous eosinophilic

Received for publication 15 April 1970. material resembling amyloid, and the development of anomalous colours when viewed between crossed polaroids (Brewer, 1964) was used as an additional check to eliminate the colloid often seen in parathyroids with a follicular pattern. Amyloid was then more definitely identified by Highman's Congo red and Thioflavine $\mathrm{T}$ stains. Methyl violet stains were used but were not consistent, being unhelpful in doubtful cases. Known primary and secondary amyloid sections were used as controls on all occasions. Examination of Congo red sections between crossed polaroids for dichroism (Ladewig, 1945) proved most useful; this method is regarded by most authorities as the best histological method for identifying amyloid (Cohen, 1967). Cases not showing dichroism were excluded. It was possible in one case to reprocess material from a paraffin block and examine it using the electron microscope.

\section{Results}

A follicular pattern is common in hyperplastic parathyroids and the follicles often contain 
Total no. of parathyroid cases examined ..... 88 Adenomas ................. 40 Hyperplasia (including one water clear cell) 48

Cases with intrafollicular amyloid deposits .... $9(10.2 \%)$

With pluriglandular syndrome $\ldots \ldots \ldots \ldots 7(7.9 \%)^{1}$ Without other associations $\quad \ldots \ldots \ldots \ldots .2(2.3 \%)$

Table I Intrafollicular amyloid in parathyroids ${ }^{1}$ No other pluriglandular cases were examined

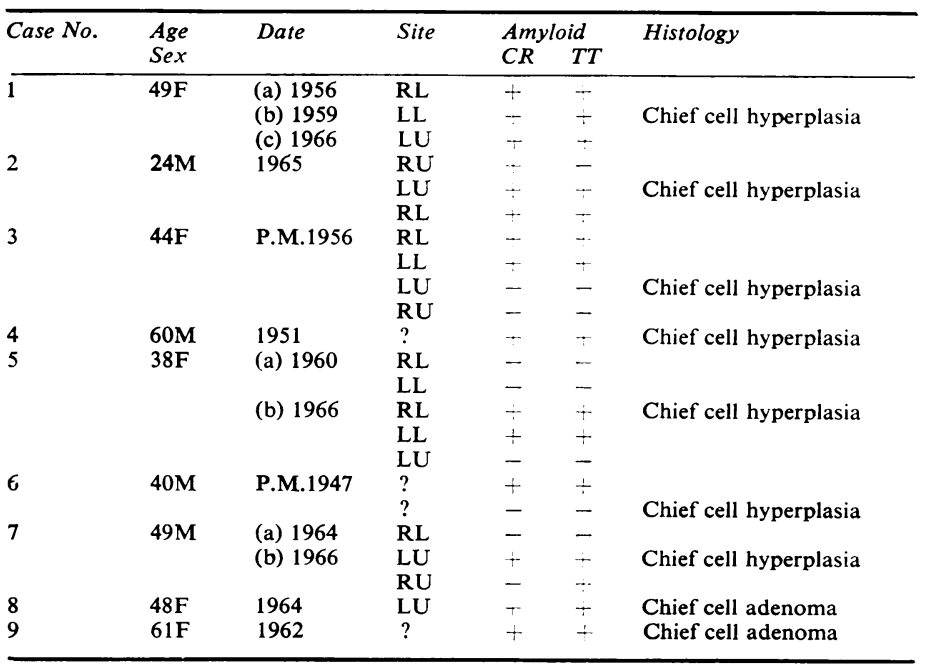

Table II Parathyroid histology

RL=right lower $\quad$ RU = right upper $\quad ?=$ site unknown $\quad$ CR=Congo Red amorphous colloid. In the present series intriक follicular amyloid deposits were detected in nine of the 88 cases examined; seven of these nir cases had suspected or proven pluriglandul $\mathbb{P}$. adenomatosis and two had no such association (Table I).

The main pathological findings in the parethyroids are summarized in Table II and thes clinical and other associated features in Tab? III.

In the nine positive cases there is a wide a range (24-61 yr) and almost equal sex distribution (five female, four male). In seven cases the gland showed chief cell hyperplasia and in the remainde्t there were chief cell adenomas. The largest am\& loid deposits were seen in the first parathyroft removed from case 1 (Table II); follicular areas showed extensive intrafollicular amyloid deposite (Fig. 1). The cells surrounding the amyloind deposits were of moderate size with a roune nucleus towards the base and the cytoplas contained clear vacuoles. The staining reactions of these cells by PAS, Best's carmine, Bodia and diazo methods did not differ from those adjacent follicular and non-follicular parathyro tissue not containing amyloid. In addition these large and obvious areas of intrafollicular amyloid the adjacent hyperplastic parathyroro contained similar small foci of amyloid within tiny follicles scattered throughout the glang (Fig. 2). It was these small deposits which we found in most of the other cases (Fig. 3), although in some (case 6) larger areas were seen (Fig. 4).

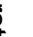
. 
was often possible to examine more than one parathyroid from each case, and indeed cases 1 , 5 , and 7 had recurrent hyperparathyroidism necessitating further operations. It is apparent (Table II) that not all parathyroids from each case showed these deposits but this may merely represent a random distribution.

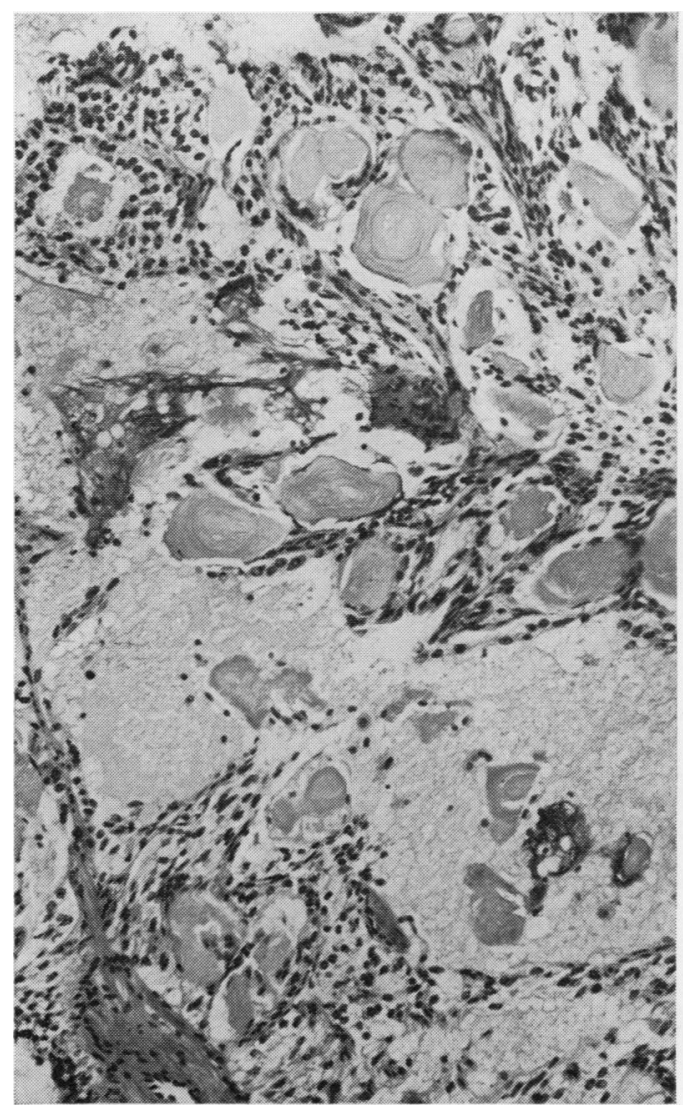

Fig. 1

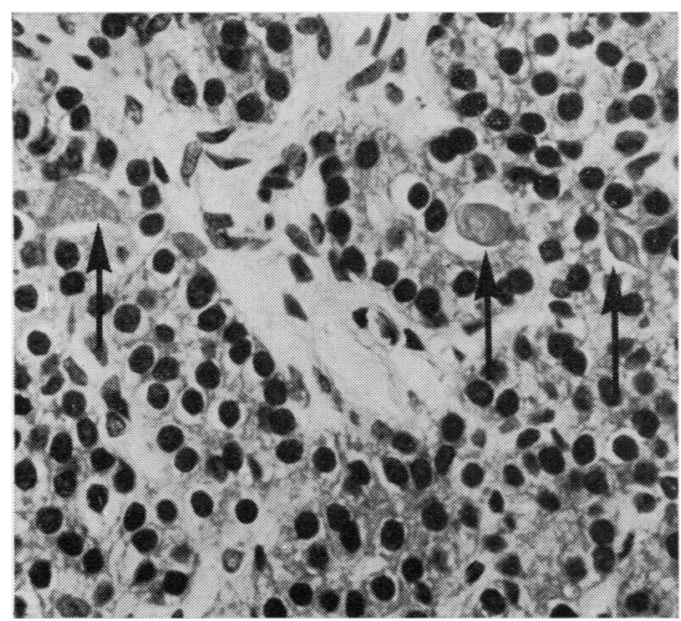

The deposits were not related to the site of the parathyroid. An impression was formed that they tend to occur near the periphery of the gland. Localized islands of these small amyloid-containing acini were not seen.

In addition to the 88 cases of primary hyperparathyroidism 20 normal parathyroids from

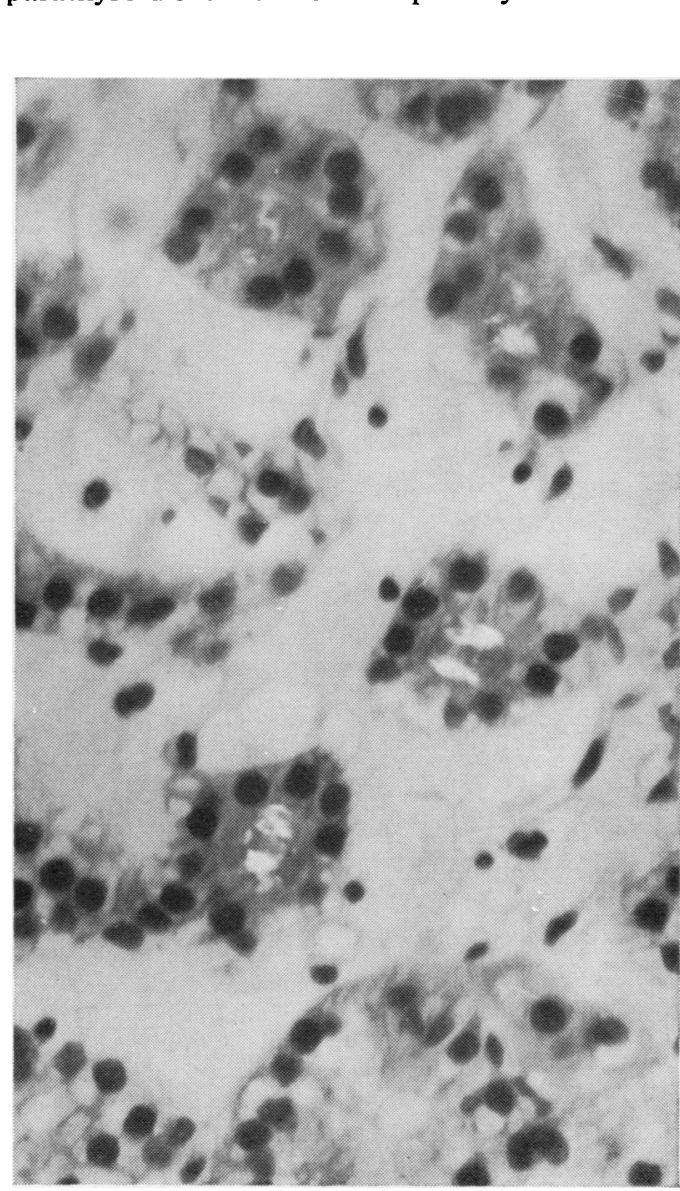

Fig. 3

Fig. 1 Case 1. Parathyroid showing extensive intrafollicular amyloid deposits. Concentric deposition is present and breakdown of follicular structure can be seen. Haematoxylin and eosin $\times 160$.

Fig. 2 Case 1. Parathyroid with chief cell hyperplasia and small, sometimes laminated intrafollicular deposits of amyloid (arrows). Haematoxylin and eosin $\times 640$.

Fig. 3 Case 9. Parathyroid adenoma showing small birefringent intrafollicular amyloid with a Maltese cross appearance. Congo red with crossed polaroids $\times 640$. 
routine postmortem cases were examined. Amyloid was not detected in any of these. Some corpora amylacea in prostate and lung were also examined. Those in the prostate took up Congo red but did not show birefringence. Some in the lung showed a regular laminated yellow-green birefringence but not the broken-up, apple-green dichroism as is seen in amyloid (Fig. 5).

\section{A MYLOID}

The amyloid present showed dichroism in sections stained with Congo red and viewed in a polarizing microscope, and green fluorescence with thioflavine $T$ stains in all cases (Fig. 5). The tiny intrafollicular deposits often gave a Maltese cross pattern of birefringence (Fig. 3). Larger deposits sometimes had a concentric layered appearance (Figs. 1 and 5). In case 1 the amyloid had broken out of some follicles into the stroma (Fig. 1) and macrophages with a few foreign body giant cells were closely applied to it within some large, possibly confluent, follicles (Fig. 6). Amyloid was not seen involving other elements.

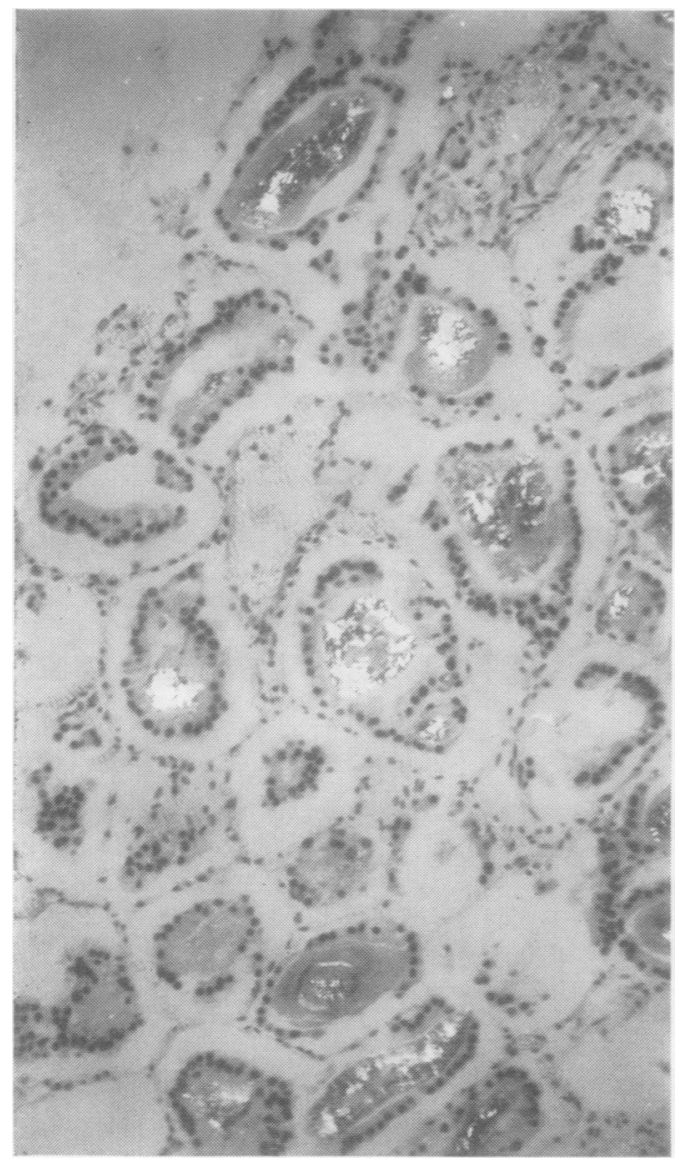

Fig. 4 Case 6. Parathyroid with large birefringent intrafollicular amyloid deposits. Congo red with crossed polaroids $\times 160$.
Electron microscopy of tissue from case showed the non-branching fibrillar networko composed of long, $75-100 \mathrm{~A}$ wide, fibres (Fig. which, together with the staining properties previously referred to, characterize amyloid: Electron microscope controls of known amyloief material, also previously paraffin-embedde appeared identical.

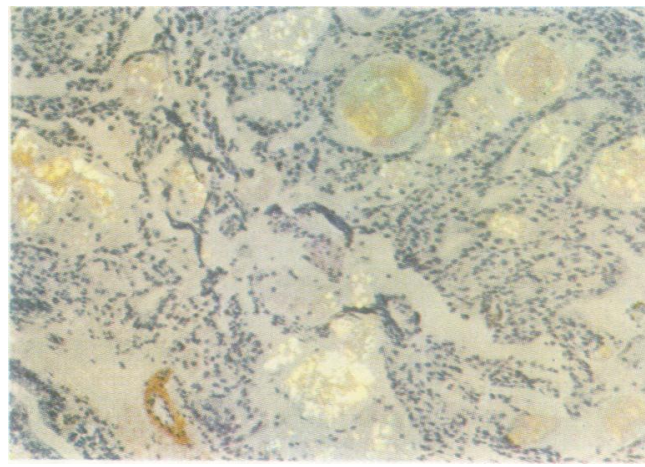

Fig. 5

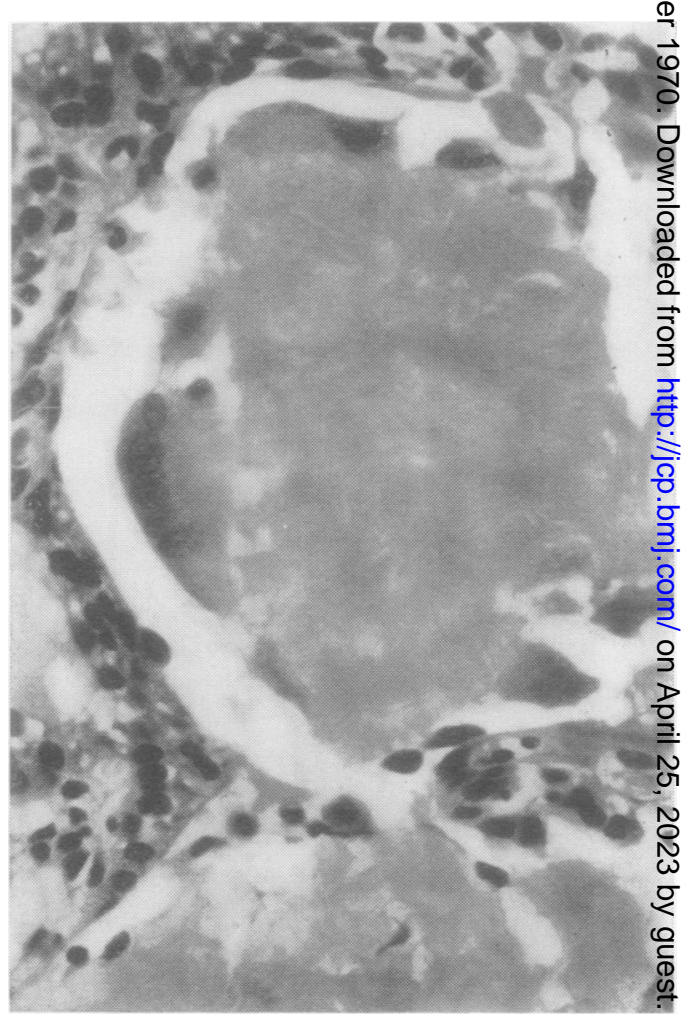

Fig. 5 Case 1. Parathyroid showing the characteristic broken-up, green-yellow dichroism of amyloid. Lamination is present in some deposits. Congo red with crossed polaroids $\times 160$.

Fig. 6 Case 1. Parathyroid amyloid with macrophage and foreign body giant cell reaction. Haematoxylin and eosin 160 . 


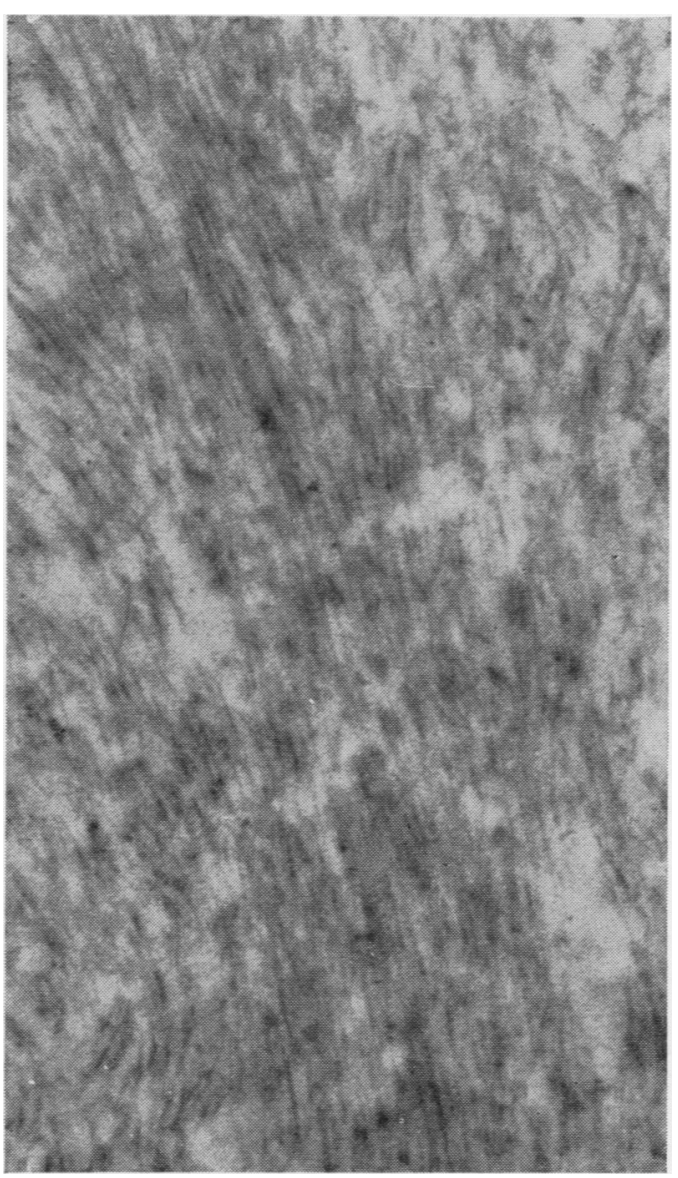

Fig. 7 Case 1. Electron microscope photograph of amyloid material removed from a paraffin block. The characteristic non-branching fibrils, 75-100A wide, are seen. Uranyl acetate $\times 60,000$.

\section{CLINICAL}

When the clinical records of cases 1, 2, 4, and 5 were examined it was realized that they were members of two families having the pluriglandular syndrome, and that case 5 had been the subject of a previous report (Greenbaum, 1960). This led to the examination of the postmortem records of case 3 (sister of case 1 ) and case 6 , the subject of a pluriglandular syndrome previously reported (Marshall and Sloper, 1954). Case 7 had had a small intestinal argentaffinoma removed and is known to have a high gastric acidity. There are therefore certainly six and probably seven cases of pluriglandular syndrome (Table III), five of these coming from two families (cases 1, $2,3,4$, and 5). The parathyroids from other members of these families who had died or had resections were not available for study. Cases 8 and 9 had no such family or personal history.

With the exception of case 2 all cases show renal calcification of greater or lesser extent, in some progressing to severe renal failure. Only case 8 had a bone lesion unequivocally due to primary hyperparathyroidism. In case 3 there was $\stackrel{\varrho}{\bar{F}}$ longstanding renal disease and case 7 had in- 0 testinal malabsorption which might have pro-duced bone changes seen radiologically. None of $\underline{\underline{O}}$ three islet cell tumours (cases 1,3 , and 6 ) contained $\underset{\vec{F}}{\overrightarrow{2}}$ amyloid.

\section{Discussion}

Amyloid deposits are not mentioned in the many $\vec{\circ}$ reviews of primary hyperplasia of the parathyroid gland (Woolner, Keating, and Black, $\vec{\omega}$ 1952; Cope, Keynes, Roth, and Castleman, 1958; Black, 1960; Pyrah, Hodgkinson, and Anderson, $\frac{8}{0}$ 1966), familial hyperparathyroidism (Cutler, ్ㅜㅇ Reiss, and Ackerman, 1964; Schachner, Riley, 0 Old, Taft, and Hamwi, 1966; Stevens, Bloomer, $\stackrel{\infty}{\rightarrow}$ and Castleton, 1967) and pluriglandular adenomatosis (Underdahl, Woolner, and Black, 1953; 을 Wermer, 1963; Ballard, Frame, and Hartsock, $\rightarrow$ 1964). The reason for this lack of previous observation may reflect the fact that only tiny $\varnothing$ deposits are present in most glands. The signifi- $\bar{\partial}$ cance of the observation is of greater interest.

It must be emphasized that these deposits do not relate to systemic amyloidosis either primary, familial, secondary, or senile. A careful study of postmortem material and records of the patients and families failed to reveal any such association. The cases presented show no predisposition to deposit amyloid anywhere other than in the parathyroid. The local amyloid must therefore be $\triangle$ interpreted with reference to similar deposits in $\overrightarrow{0}$ other endocrine-secreting tissue and to the normal or abnormal functions of the parathyroid glands.

The isolated amyloid fibril has been shown to be a protein (Cohen, 1966), and therefore largely composed of peptides. Local deposits of amyloid are known to occur in islet cell tumours of the pancreas (Porta et al, 1962), medullary carcinoma of the thyroid (Hazard, Hawk, and Crile, 1959; Williams et al, 1966), and are now shown in the parathyroid. Peptide hormones are produced at $\frac{D}{0}$ all these sites and it is possible that the amyloid may represent polymerization of an aberrant $N$ peptide which may or may not be related to the $N$ particular hormone. However, amyloid deposits N have not been recorded in pituitary tumours, carcinoid tumours, or oat-cell carcinoma of the bronchus associated with endocrine syndromes, all of which are known to produce peptide $\stackrel{\mathbb{S}}{\rightarrow}$ hormones. Thus the relationship may be more specifically with the three sites mentioned.

Amyloid deposits are a prominent feature of $\overparen{D}$ medullary carcinoma of the thyroid but their $\frac{O}{\mathbb{D}}$ significance has not been elucidated and is not referred to in reviews of the subject (Hazard et al, 1959; Williams et al, 1966). In these tumours the 8 amyloid is stromal and not intrafollicular as in the parathyroids, where the appearances suggest 
a relationship to the secretions of surrounding cells. Small amyloid deposits completely surrounded by tumour cells are present in some medullary carcinomas (Williams et al, 1966). Tissue culture of medullary carcinoma shows rosette formation by the tumour cells with amyloid at the centre (Albores-Saavedra, Rose, Ibanez, Russell, Grey, and Dmochowski, 1964), and amyloid fibrils have been seen in the cytoplasm of the tumour cells indicating production of amyloid by these cells (Gonzalez-Licea, Hartmann, and Yardley, 1968; Meyer, 1968). The intrafollicular position of the amyloid in the parathyroids has the same connotation, and it should be noted that it is only in the larger follicles that macrophages can be seen and not in the tiny acini where amyloid is presumably just beginning to be deposited.

It has been shown that medullary carcinoma secretes calcitonin (Tashjian and Melvin, 1968; Cunliffe, Black, Hall, Johnston, Hudgson, Shuster, Gudmundsson, Joplin, Williams, Woodhouse, Galante, and MacIntyre, 1968; Tubiana, Milhaud, Coutis, Lacour, Parmentier, and Bok, 1968), a peptide hormone with hypocalcaemic and hypophosphataemic action due to inhibition of bone resorption (Copp, Cameron, Cheney, Davidson, and Henze, 1962; Friedmann and Raisz, 1965). Calcitonin-like activity has also been identified in normal human plasma (Gudmundsson, Byfield, Galente, Kenny, MacIntyre, Osafo, and Tse, 1968), and it is probable that this hormone directly opposes parathormone in its bone resorptive action. Calcitonin is secreted by C-cells (Pearse, 1966) derived from the last branchial pouch, and medullary carcinoma of thyroid is almost certainly a tumour of these cells (Williams, 1966). Amyloid deposition may be directly related to calcitonin secretion in medullary carcinoma, possibly representing aggregates of a closely related polypeptide produced by altered cellular metabolism, or even a normal calcitonin precursor produced in excess. Thus it may act as a marker of calcitonin secretion, and it is suggested that the same may apply in the parathyroid. Hypercalcaemia and calcitonin secretion are not incompatible as calcitonin only opposes parathormone in its actions on bone and not its effects in increasing calcium absorption from the intestinal tract (Spencer, Lewin, and Samachson, 1968).

In support of the 'marker' hypothesis it should be noted that calcitonin activity has been shown in the human parathyroid, thyroid, and thymus (Galante, Gudmundsson, Matthews, Tse, Williams, Woodhouse, and MacIntyre, 1968). Thus it would appear that C-cells can be incorporated embryologically into all three glands. It would also be more likely that a hyperplastic or adenomatous gland would produce peptides closely related to its normal metabolism, whereas a variety of unrelated peptides might be produced by a neoplastic cell.

Against this view it might be argued first that intrafollicular amyloid should be seen in hyper- parathyroidism much more frequently than indicated by the present study since the stimuluso for calcitonin release is hypercalcaemia (Cop et al, 1962; Kumar, Foster, and MacIntyre, 1963)을 However, it is not known whether the normat distribution of C-cells is uniform between para thyroid, thyroid, and thymus, and it is possible that there is considerable individual variation: search for tiny deposits of amyloid within the

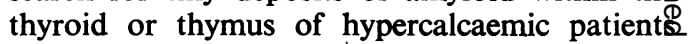
might be rewarding. Secondly there is our in ability in this material either to identify the follicular cells as C-cells or to differentiate them. from the surrounding parathyroid cells not associated with amyloid. C-cells are argyroph $\frac{\mathbb{P}}{\mathrm{S}}$ (Nonidez, 1932) but, since argyrophilia is also one of the characteristics of normal parathyroid cellid (Roth, 1962), it is not a distinguishing characterio istic. More detailed identification of these follpo cular cells must await the availability of materiat suitable for electron microscopy allowing a searc\& for the secretory granules as seen in C-cells (Meyer and Abdel-Bari, 1968) and for immunofluorescent studies to locate the site of calcitonin production in the parathyroid.

If amyloid deposition does relate to calcitonip in medullary carcinoma and hyperparathyroidism it is difficult to associate this with the amyloid seen in islet cell tumours. Islet cells are derived from the foregut and have much in common witb the other endocrine derivatives of this region. is known that islet cell tumours may produce several peptide hormones but calcitonin has no been identified. However, glucagon, also a low molecular weight peptide hormone, has bee $\vec{B}$ shown to have a hypocalcaemic action in the rat (Williams, Bowser, and Henderson, 1969).

The association of the intrafollicular amyloif deposits with the pluriglandular adenomatosis syndrome in seven of the cases may merely refle the long duration of disturbed calcium metabo lism. It is well known that hypercalcaemia is often asymptomatic in these families.

Thus it would appear that there are two possible explanations for the presence of intrafollicular amyloid in parathyroids in primary hyperpars thyroidism: (1) a non-specific relationship wit cells capable of peptide synthesis, or (2) a mok specific association with a peptide related to calcitonin. The latter seems more likely at presenf but will remain speculative until more inform标 tion is available concerning calcitonin levels in cases of primary and secondary hyperparathyroi ism, and the site of calcitonin production in the parathyroids is identified by histochemical, immunofluorescent, and electron microscope methods.

We wish to thank Dr S. Mason for allowing us study his clinical records and Professor E. Wright for giving access to pathological materiag. We are grateful to Professor I. Doniach for hes encouragement and criticism of the manuscrip 
Mr V. Trenwith, Miss L. Beard, and Mr R. Hammond are thanked for technical, secretarial, and photographic assistance, and Mr A. Gray for the electron microscopy.

\section{References}

Albores-Saavedra, J., Rose, G. G., Ibanez, M. L., Russell, W. O. Grey, C. E., and Dmochowski, L. (1964). The amyloid in solid carcinoma of the thyroid gland, staining characteristics, tissue culture and EM observations. Lab. Invest., 13, 77-93.

Ballard, H. S., Frame, B., and Hartsock, R. J. (1964). Familial multiple endocrine adenoma-peptic ulcer complex. Medicine (Baltimore), 43, 481-516.

Black, B. M. (1960). The Parathyroids, pp. 427-438. Thomas, Springfield, Illinois.

Brewer, D. B. (1964). Renal Biopsy, p. 20. Arnold, London.

Cohen, A. S. (1966). Preliminary chemical analysis of partially purified amyloid fibrils. Lab. Invest., 15, 66-83.

Cohen, A.S. (1967). Amyloidosis. New Engl. J.|Med., 277, 522-530.

Cope, O., Keynes, W. M., Roth, S. I., and Castleman, B. (1958). Primary chief cell hyperplasia of the parathyroid glands: a new entity in surgery of hyperparathyroidism. Ann. Surg., 148, 375-388.

Copp, D. H., Cameron, E. C., Cheney, B. A., Davidson, A. G. F., and Henze, K. G. (1962). Evidence for calcitonin-a new hormone from the parathyroid that lowers blood calcium. Endocrinology, 70, 638-649.

Cunliffe, W. J., Black, M. M., Hall, R., Johnston, I. D. A., Hudgson, P., Shuster, S., Gudmundsson, T. V., Joplin, G. F., Williams, E. D., Woodhouse, N. J. Y., Galante, L. and MacIntyre, I. (1968). A calcitonin-secreting thyroid carcinoma. Lancet, 2, 63-66.

Cutler, R. E., Reiss, E., and Ackerman, L. V. (1964). Familial hyperparathyroidism: a kindred involving eleven cases with a discussion of primary chief-cell hyperplasia. New Engl. J. Med., 270, 859-865.

Friedman, J., and Raisz, L. G. (1965). Thyrocalcitonin: inhibitor of bone resorption in tissue culture. Science, 150, 14651467.

Galante, L., Gudmundsson, T. V., Matthews, E. W., Tse, A. Williams, E. D., Woodhouse, N. J. Y., and MacIntyre, I. (1968). Thymic and parathyroid origin of calcitonin in man. Lancet, 2, 537-538.

Gonzalez-Licea, A., Hartmann, W. H., and Yardley, J. H. (1968). Medullary carcinoma of the thyroid. Ultrastructural evidence of its origin from the parafollicular cell and its possible relation to carcinoid tumours. Amer. J. clin. Path., 49, 512-520.

Greenbaum, D. (1960). Multiple familial parathyroid adenomata. Proc. roy. Soc. Med., 53, 903.

Gudmundsson, T. V., Byfield, P. G. H., Galente, L., Kenny, A. D., Macintyre, I., Osafo, T. D., and Tse, A. (1968). Calcitonin in blood. (Abstr.). Calcif. Tiss. Res., 2, Suppl. 17.

Hazard, J. B., Hawk, W. A., and Crile, G., Jr. (1959). Medullary (solid) carcinoma of the thyroid-a clinicopathological entity. J. clin. Endocr., 19, 152-161.

Kumar, M. A., Foster, G. V., and MacIntyre, I. (1963). Further evidence for calcitonin, a rapid-acting hormone which lowers plasma-calcium. Lancet, 2, 480-482.

Ladewig, P. (1945). Double-refringence of the amyloid-CongoRed-complex in histological sections. Nature (Lond.), 崽 156, 81-82.

Marshall, A. H. E., and Sloper, J. C. (1954). Pluriglandular 음 adenomatosis of the pituitary, parathyroid and pancreatic- $\Rightarrow$ islet cells associated with lipomatosis. J. Path. Bact., 68, $\overrightarrow{\mathcal{C}}$ 225-229.

Meyer, J. S. (1968). Fine structure of two amyloid-forming medullary carcinomas of thyroid. Cancer (Philad.), 21, 406-425.

Meyer, J. S., and Abdel-Bari, W. (1968). Granules and thyro- $\frac{\mathcal{S}}{\partial}$ calcitonin-like activity in medullary carcinoma of thyroid gland. New Engl. J. Med., 278, 523-529.

Nonidez, J. F. (1932). Further observations on the parafollicular $\mathcal{O}$ cells of the mammalian thyroid. Anat. Rec., 53, 339-353.

Pearse, A. G. E. (1966). The cytochemistry of the thyroid C cells and their relationship to calcitonin. Proc. roy. Soc. B., $164,478-487$.

Porta, E. A., Yerry, R., and Scott, R. F. (1962). Amyloidosis of $\mathscr{\omega}$ functioning islet cell adenomas of the pancreas. Amer. J. Path., 41, 623-627.

Pyrah, L. N., Hodgkinson, A., and Anderson, C. K. (1966). iv Primary hyperparathyroidism. Brit. J. Surg., 53, 245- W 316.

Roth, S. M. (1963). Pathology of the parathyroids in hyperpara- $\infty$ thyroidism-discussion of recent advances in anatomy and = pathology of parathyroid glands. Arch. Path., 73, 495-510.

Schachner, S. H., Riley, T. R., Old, J. W., Taft, D. A., and Hamwi, G. J. (1966). Familial hyperparathyroidism. Arch. intern. Med., 117, 417-421.

Spencer, H., Lewin, I., and Samachson, J. (1968). Absorption of calcium in hyper- and hypo-parathyroidism in man (Abstr. 135). In Proc. 3rd inter. Congr. Endocr., p. 54. Excerpta Medica.

Stevens, L. E., Bloomer, A., and Castleton, K. B. (1967). Familial hyperparathyroidism. Arch. Surg., 94, 524-531.

Tashjian, A. H., Jr., and Melvin, K. E. W. (1968). Medullary carcinoma of the thyroid gland-studies of thyrocalcitonin in plasma and tumour extracts. New. Engl. J. Med., 279, 279-283.

Tubiana, M., Milhaud, G., Coutris, G., Lacour, J., Parmentier, C., and Bok, B. (1968). Medullary carcinoma and thyrocalcitonin. Brit. med. J., 4, 87-89.

Underdahl, L. O., Woolner, L. B., and Black, B. M. (1953). Multiple endocrine adenomas: report of 8 cases in which the parathyroids, pituitary and pancreatic islets were involved. J. clin. Endocr., 13, 20-47.

Wermer, P. (1963). Endocrine adenomatosis and peptic ulcer in a large kindred; inherited multiple tumours and mosaic pleiotropism in man. Amer. J. Med., 35, 205-212.

Williams, E. D. (1966). Histogenesis of medullary carcinoma of the thyroid. J. clin. Path., 19, $114-118$.

Williams, E. D., Brown, C. L., and Doniach, I. (1966). Pathological and clinical findings in a series of 67 cases of medullary carcinoma of the thyroid. J. clin. Path., 19, 103-113.

Williams, G. A., Bowser, E. N., and Henderson, W. J. (1969). Mode of hypocalcemic action of glucagon in the rat. Endocrinology, 85, 537-541.

Woolner, L. B., Keating, F. R., Jr., and Black, B. M. (1952). Tumours and hyperplasia of the parathyroid glands-a review of the pathological findings in 140 cases of primary hyper-parathyroidism. Cancer (Philad.), 5, 1069-1088. 